MONIKA MASALON

AleKSANDRA KulińSKA

SYLWIA BRUNA

Pracownia Inicjatyw Społecznych DYM

\title{
Teren uzmysłowiony
}

Tiniejszy artykuł jest efektem namysłu nad projektami, które zrealizowa-
łyśmy dotychczas w ramach stowarzyszenia „Pracownia Inicjatyw Społecznych DYM". Tematowi uzmysłowienia przyglądałyśmy się z różnych stron. Zdecydowałyśmy, że skoncentrujemy się na pojęciu terenu, a dokładniej na kwestii uzmysłowienia, czyli uświadomienia sobie, gdzie i czym jest dla nas teren rzeczywisty, czyli taki, w który wchodzi się fizycznie, dosłownie. Ale także, czym jest teren metaforyczny, którego zakres - jak okaże się w tekście - jest trudny do jednoznacznego zdefiniowania i zamknięcia w określone ramy. Będzie to zatem opowieść o uświadamianiu terenu przez nas - członkinie stowarzyszenia - oraz u nas - w działaniach, które w ramach stowarzyszenia proponujemy.

Refleksje nad terenem zajmują antropologów już od dawna. Tarzycjusz Buliński i Mariusz Kairski piszą o redefinicji terenu w następujący sposób:

Klasyczne „bycie Tam” przestało być takie oczywiste. Wcześniej wystarczyło wyjechać do Innych, którzy - według perspektywy antropologa - żyli na jakimś wyraźnie dającym się określić obszarze (...). Ale dzisiaj, gdy Inni przyjeżdżają do świata badaczy, by równocześnie żyć i Tutaj, i Tam (np. za pomocą Internetu czy telefonu utrzymują intensywne relacje z mieszkającymi Tam krewnymi), lub gdy antropolog poszukuje swojskich Innych we własnym świecie, sprawy się komplikują. Nasze obiekty badań nie są już takie jednoznaczne (Buliński, Kairski 2013: 11-12). 
Powyższy cytat skłonił nas do rozważań nad tym, czym jest teren dla nas i jak go rozumieć w kontekście działań i projektów, które dotychczas realizowałyśmy jako Pracownia Inicjatyw Społecznych DYM.

Kiedy w 2016 roku planowałyśmy nasz pierwszy projekt, zaufałyśmy intuicji i poszłyśmy za tym, co nas najbardziej interesowało. Pomysły na kolejne działania pojawiały się spontanicznie - po przeczytaniu ciekawego artykułu, spotkaniu z inspirującym człowiekiem, odwiedzeniu nowego miejsca. Dopiero teraz, w momencie pisania tego tekstu, przyszedł czas na zrewidowanie dotychczasowej pracy. Punktem styku wszystkich zrealizowanych pomysłów okazał się być teren, traktowany jako miejsce (w terenie) albo jako kategoria (o terenie).

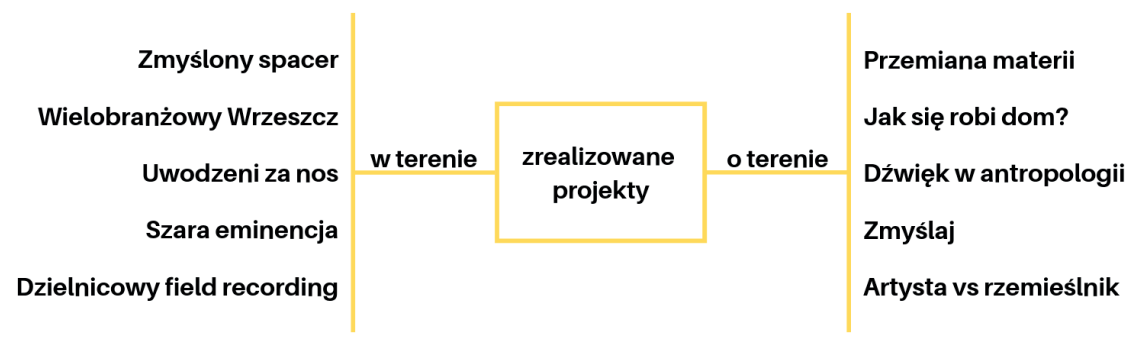

\section{W terenie}

„Likwidacja sklepu!!! Po 25 latach działalności od dnia 28.06.2017 zamknięte! Pozdrawiamy naszych klientów i życzymy im wszystkiego dobrego!!!"

podpisano Elegant

Elegant był kultowym sklepem z garniturami w gdańskim Wrzeszczu. Kartkę z powyższym komunikatem zamieszczonym na jego drzwiach przeczytałyśmy na chwilę przed rozpoczęciem projektu „Wielobranżowy Wrzeszcz”. Rozmowa z właścicielem sklepu miała być pierwszą, którą przeprowadzimy. To zdarzenie utwierdziło nas w przekonaniu, że opowieści o handlowej historii tej dzielnicy nie można odłożyć na później.

Małe punkty usługowe mijane codziennie wywoływały w nas ciekawość zaglądałyśmy w ich okna, szukając tajemnic i dodatkowego znaczenia. Podglądanie stało się naszym małym rytuałem. "Wielobranżowy Wrzeszcz” to pierwszy projekt, w którym spełniłyśmy wszystkie - na tamten czas - miejskie ciągoty: zaglądanie w zakamarki dzielnicy, rozmowy z lokalnymi dziwakami, z którymi zwykle trudno nam zamienić słowo bez powodu, wpraszanie się i poznawanie 
miejsc, które wcześniej tylko mijałyśmy. Naszym założeniem było odszukanie małych, często kultowych na mapie dzielnicy punktów usługowych, prowadzenie rozmów z ich właścicielami lub pracownikami, uwiecznienie i przekazywanie ich historii.

Po raz pierwszy wyszłyśmy w miejski teren, pełen neonów, hałasów i zapachu spalin. Teren, który w niczym nie przypominał tego, co znałyśmy ze studenckich wyjazdów na wieś, gdzie odległość między kolejnymi domostwami pokonywałyśmy rowerem, a badawczy dzień kończył się wspólnym, etnologicznym ogniskiem i rozmowami do rana. Nasz teren był tuż za rogiem, między ulubioną piekarnią a apteką. Nie wymagał od nas uruchomienia aplikacji Google Maps ani pogłębionego researchu. Wystarczyło wyjść na rozeznanie wokół domu, a naszym oczom kolejno ukazywały się miejsca, których szukałyśmy. Nieco zapomniane, jakby wyjęte z poprzedniej epoki, niewidoczne w gąszczu innych, świecących nowością marketów. Zegarmistrz, krawiec, sprzedawca w barze mlecznym, cukiernik - za każdym z tych zawodów kryje się nie tylko konkretny zestaw umiejętności, ale i konglomerat skojarzeń i znaczeń.

Nasze bycie w terenie różni się od klasycznego rozumienia badań etnograficznych. Nie wyjeżdżamy w nieznane - po prostu wychodzimy z domu. Nie wracamy z terenu, ponieważ cały czas w nim jesteśmy. „Innych” spotykamy w sklepie, kawiarni, w drodze do pracy. Fizyczny teren wiąże się dla nas z konkretnymi, często najbliższymi miejscami, mijanymi na co dzień ludźmi, wrażeniami, które w nas wywołują. Jesteśmy w Gdańsku i to z niego uczyniłyśmy przestrzeń naszych eksploracji. To miasto, w którym mieszkamy, pracujemy, realizujemy projekty społeczne. Miasto, które wciąż wytwarzamy na nowo. Nie jesteśmy w stanie „dotknąć” Gdańska jako takiego, dlatego nasze działania kierujemy do konkretnych jego części, dzielnic. To, co przyświeca nam w działaniach dzielnicowych, to idea udomowienia - poznawania, polubienia, oswajania i kształtowania miejsc, w których się żyje.

Nasze bycie $w$ terenie to też branie odpowiedzialności i nieustanny sprawdzian dla uważności. Jeżeli popełnimy błąd, to (już) wiemy, że ktoś bardzo szybko nam go wytknie. Tak zresztą stało się w przypadku pana Sławka, właściciela sklepu ze starociami, podczas finału projektu „Wielobranżowy Wrzeszcz”, którego efektem było stworzenie mapy wielobranżowej dzielnicy. Przez pomyłkę błędnie umieściłyśmy na niej lokal pana Sławka, o czym rozżalony, bez zawahania nam przypomniał. Badania „u siebie” to bycie $\mathrm{w}$ terenie nonstop, nie tylko w czasie zbierania materiału.

Każdy z nas doświadcza terenu wieloma zmysłami. Nasze odczucia i wrażenia są jednak odmienne, ponieważ różnimy się pod względem „wyczulenia” konkretnych zmysłów oraz aktualnej gotowości na poznawanie otoczenia. Z tego powodu w naszych działaniach społecznych kładziemy szczególny nacisk na subiektywne sposoby odbierania i wyrażania świata. Kiedyś wymieniałyśmy się doświadczeniami i wrażeniami we własnym gronie, dziś cieszymy się, że możemy robić to na szerszą skalę i że włączają się do tego inni. I właśnie te subiektywne głosy interesują nas w terenie najbardziej. 
Krótko mówiąc, projekt „Wielobranżowy Wrzeszcz” uzmysłowił nam, w jakim terenie jesteśmy i działamy, a także, że nieustanne bycie w nim - pomimo nierzadkich trudności - wciąż budzi naszą ciekawość.

\section{O terenie}

W naszym słowniku słowo teren funkcjonuje także w innym, bardziej metaforycznym i niejednorodnym znaczeniu. Terenem bowiem okazują się nie tylko fizyczne miejsca, ale także różne tematy i związana z nimi wiedza. Tematy, które są w nas żywe, co do których mamy ciągłą potrzebę aktualizowania i pogłębiania. To one wyznaczają kierunek i dostarczają narzędzi do poszukiwań w fizycznym terenie. Różnica między nimi polega także na tym, że o ile odwiedzane miejsca ograniczają nas terytorialnie, o tyle ograniczeniem metaforycznego terenu jest przede wszystkim nasza wyobraźnia.

Myślenie i rozmawianie „o terenie” realizujemy między innymi poprzez spotkania, warsztaty i wykłady. Do ich współorganizacji zapraszamy wszystkich tych, którzy są zaciekawieni bliskimi nam tematami. Do tej pory były to obszary związane z rewitalizacją, udomowieniem, nagraniami terenowymi czy zmysłami.

Można powiedzieć, że nasze myślenie „o terenie” zmieniało się w czasie działania w stowarzyszeniu. Zaczęłyśmy nieśmiało, od oddania głosu tym, których cenimy i od których chciałyśmy się uczyć. Do opowieści o swoim terenie zaprosiłyśmy między innymi Agatę Stanisz z Uniwersytetu im. Adama Mickiewicza w Poznaniu, Magdę Prokopczuk z warszawskiej Akademii Pedagogiki Specjalnej czy Anię Rumińską z Uniwersytetu Wrocławskiego. Stopniowo i w nas zaczynała rodzić się potrzeba samodzielnego zabrania głosu. Uznałyśmy, że przestrzeń akademicka będzie tą, w której najlepiej odnajdziemy się w nowej dla nas roli. Na zaproszenie FairArt Foundation, w gdańskiej Akademii Sztuk Pięknych prowadziłyśmy warsztaty „Artysta-rzemieślnik. Metody poznania w antropologii”. Ich głównym założeniem było pogłębienie refleksji nad tym, w jaki sposób kreujemy świat, a ściślej rzecz ujmując, jak kreujemy wizerunek artysty i rzemieślnika. Wspólnie z uczestnikami warsztatów zastanawiałyśmy się nad tym, co decyduje o kształtowaniu się naszych wyobrażeń i poglądów, a także definicji i funkcji sztuki i rzemiosła. Czy jesteśmy w stanie jednoznacznie stwierdzić, co wpływa na nasze myślenie? Jakie narzędzia poznawcze wykorzystujemy? Na tak postawione pytania próbowałyśmy szukać odpowiedzi z uczestnikami spotkania. To one wyznaczały obszar naszego terenu.

Inny - szczególnie dla nas ważny - projekt realizowałyśmy we współpracy z Uniwersytetem Gdańskim. „Dźwięk w antropologii”, czyli cykl spotkań ze studentami etnologii, których celem było zapoznanie z metodami pracy terenowej z wykorzystaniem narzędzi, jakimi są nagrania terenowe. Poznanie zagadnień związanych z antropologią dźwięku, a także wspólne tworzenie, odsłuchiwanie i analizowanie nagrań pozwoliło nam nie tylko przyjrzeć się fizycznemu terenowi badań, ale także go posłuchać. 
Jak uzmysłowiłyśmy sobie podczas pracy nad tym artykułem, znacznie trudniej jest nam pisać "o terenie" niż być „W terenie” oraz opowiadać o zbieranych w nim historiach i doświadczeniach. Teren metaforyczny wymyka się ścisłym ramom, stale poszerza pola oddziaływań i generuje nowe pytania. Jest dynamiczny, zmienny i niejednolity.

\section{Zakończenie}

Jak pokazują nasze doświadczenia, terenem można nazwać wszystko. A może i wszystkich. Terenem przecież też są ludzie, o których myślimy i z którymi pracujemy. Terenem są pojedyncze momenty, ale i powtarzające się sytuacje. Jak pisałyśmy wcześniej, ramy i znaczenie terenu wyznacza przede wszystkim nasza wyobraźnia. Ze względu na ograniczoną objętość artykułu nie byłyśmy w stanie rozwinąć wszystkich wątków, które nas pociągały. Powstały artykuł jest podsumowaniem pewnego etapu naszej działalności w ramach stowarzyszenia, a także zaproszeniem do przyjrzenia się naszemu rozumieniu i nazywaniu rzeczywistości.

\section{Opis projektów:}

\section{W TERENIE}

Wielobranżowy Wrzeszcz. W ramach projektu badawczego zebrałyśmy 11 historii właścicieli małych punktów usługowych, którzy od kilkudziesięciu lat niezmiennie tworzą historię handlowej dzielnicy Gdańska. Projekt został zrealizowany w ramach programu "Zrozumieć Sierpień 7", realizowanego przez Europejskie Centrum Solidarności.

Dzielnicowy fieldrecording. Projekt dźwiękowy, którego celem jest promowanie świadomej praktyki słuchania i uwrażliwiania na różnorodny, miejski pejzaż dźwiękowy. Do tej pory nagrane zostały fragmenty codzienności takich dzielnic, jak: Orunia, Wrzeszcz, Górki Zachodnie, Morena, VII Dwór, Brzeźno czy Śródmieście. Projekt realizujemy w trybie ciągłym.

(U)wodzeni za nos. Warsztaty sensoryczne, których celem było ukazanie tego, jak zmysł węchu i otaczające świat zapachy w pływają na jednostkę i jej percepcję rzeczywistości. Warsztaty zostały zrealizowane w ramach programu „Otwarty IKM” realizowanego przez Instytut Kultury Miejskiej w Gdańsku.

Zmyślony spacer. Rodzaj warsztatów sensorycznych, których celem jest poznanie miasta innymi zmysłami niż wzrok. Podczas spaceru z zasłoniętymi oczami uczestnicy doświadczają barier, które na co dzień napotykają osoby z niepełnosprawnością wzroku.

Szara eminencja. Projekt badawczo-artystyczny skierowany do najmłodszych mieszkańców rewitalizowanych gdańskich dzielnic: Oruni i Biskupiej Górki. Dzieci jako królowe i królowie dzielnicy pokazywały nam swoje ulubione miejsca, rejestrując je w obiektywie aparatu. Projekt został zrealizowany w ramach programu rewitalizacji miasta Gdańsk. 


\section{O TERENIE}

Przemiana materii. Rewitalizacja - strategia dla ludzi czy urzędów. Wykład Anny Rumińskiej (Uniwersytet Wrocławski) na temat do-społecznych strategii rewitalizacji miejskiej z perspektywy etnologii i antropologii kulturowej oraz antropologii architektury. Warsztaty zostały zrealizowane w ramach programu "Otwarty IKM" realizowanego przez Instytut Kultury Miejskiej w Gdańsku.

Jak się robi dom? Wykład Agaty Stanisz (Uniwersytet im. A. Mickiewicza) poruszający temat antropologii domu, rzeczy i codzienności. Wykład został zrealizowany w ramach programu „Otwarty IKM" realizowanego przez Instytut Kultury Miejskiej w Gdańsku.

Dźwięk w antropologii. Cykl zajęć, których celem było zapoznanie studentów etnologii z metodami pracy terenowej z wykorzystaniem narzędzi, jakimi są nagrania terenowe. Przedmiot był realizowany w ramach współpracy z Uniwersytetem Gdańskim.

Zmyślaj. Warsztaty sensoryczne mające na celu powrót do prostych doznań, które budują nasze poczucie rzeczywistości i stanowią podstawę relacji ze światem, ze sobą, z innymi ludźmi. Warsztaty zostały zrealizowane w ramach programu „Otwarty IKM" realizowanego przez Instytut Kultury Miejskiej w Gdańsku.

Artysta/rzemieślnik. Metody poznania w antropologii. Założeniem warsztatów było pogłębienie refleksji nad tym, w jaki sposób kreujemy świat, a ściślej rzecz ujmując - jak kreujemy wizerunek artysty i rzemieślnika. Warsztaty zostały zrealizowane $\mathrm{w}$ ramach Festiwalu Arts\&Crafts, projektu „Artonautyka” organizowanego przez Fundację FairArts.

Pracownia Inicjatyw Społecznych DYM - gdańskie stowarzyszenie tworzone przez antropolożki zafascynowane miastem i mikroświatem, jaki tworzą dzielnice. Od ponad trzech lat inicjują działania nieoczywiste, a jednocześnie proste, dotyczące zwykłych ludzi, codzienności i miejsc, w których mieszkają. Ich filozofią jest uzmysławianie udomowienia. Fanki papierowych czasopism i smutnej muzyki. Zawsze mają przy sobie dyktafon i czas na rozmowy z lokalsami.

www.pracowniadym.pl

www.facebook.com/pracowniadym

\section{Literatura}

Buliński, T., Kairski, M. (red.) (2013). Teren w antropologii. Praktyka badawcza we wspótczesnej antropologii kulturowej. Poznań: Wydawnictwo Naukowe UAM.

\section{SUMMARY}

Sensing the Fieldwork

This text is an attempt to seek answers about field and its multi-sensory experience in research work and social activities. The work experience of Lab of Social Initiatives 
DYM was thus collected and described in order to define two categories of the field and the process of its perception.

Keywords: fieldwork, urban anthropology, urban space, Gdańsk, "locals" 